\title{
ResearchOnline@JCU
}

This is the author-created version of the following work:

Rowe, Cassandra, David, Bruno, Mialanes, Jerome, Ulm, Sean, Petchey, Fiona, Aird, Samantha, McNiven, Ian J., Leavesley, Matthew, and Richards, Thomas (2020) A Holocene record of savanna vegetation dynamics in southern lowland Papua New Guinea. Vegetation History and Archaeobotany, 29 (1) pp. 1-14.

Access to this file is available from:

https://researchonline.jcu.edu.au/57885/

Copyright (C Springer-Verlag GmbH Germany, part of Springer Nature 2019. The Accepted Manuscript version of this article is available Open Access from ResearchOnline@JCU.

Please refer to the original source for the final version of this work: 


\section{A Holocene record of savanna vegetation dynamics in southern lowland Papua New Guinea}

Cassandra Rowe $e^{\mathrm{a}, \mathrm{d}^{*}}$, Bruno David ${ }^{\mathrm{c}, \mathrm{g}}$, Jerome Mialanes ${ }^{\mathrm{c}, \mathrm{g}}$, Sean Ulm ${ }^{\mathrm{b}, \mathrm{d}}$, Fiona Petchey ${ }^{\mathrm{d}, \mathrm{e}}$, Samantha Aird ${ }^{\mathrm{b}}$, Ian J. McNiven ${ }^{c, g}$, Matthew Leavesley ${ }^{\mathrm{b}, \mathrm{d}, \mathrm{f}}$ and Thomas Richards ${ }^{\mathrm{g}}$

a College of Science and Engineering, James Cook University, P.O. Box 6811, Cairns, Queensland, 4870, Australia, e-mail: cassandra.rowe@jcu.edu.au

b College of Arts, Society and Education, James Cook University, P.O. Box 6811, Cairns, Queensland, 4870, Australia

c ARC Centre of Excellence for Australian Biodiversity and Heritage, 20 Chancellors Walk, Monash University, Clayton, Victoria 3800, Australia

d ARC Centre of Excellence for Australian Biodiversity and Heritage, James Cook University, P.O. Box 6811, Cairns, Queensland, 4870, Australia

e Waikato Radiocarbon Dating Laboratory, University of Waikato, Hillcrest Road, Hamilton, 3240, New Zealand

f Division of Anthropology, Sociology and Archaeology, School of Humanities and Social Sciences, University of Papua New Guinea, PO Box 320, University 134, National Capital District, Papua New Guinea g Monash Indigenous Studies Centre, 20 Chancellors Walk, Monash University, Clayton, Victoria, 3800, Australia

* Corresponding author 


\begin{abstract}
The southern lowlands of Papua New Guinea (PNG) are biogeographically distinct. Vast tracts of savanna vegetation occur there and yet most palaeoecological studies have focused on highlands and/or forest environments. Greater focus on long-term lowland environments provides a rare opportunity to understand and promote the significance of local and regional savannas, ultimately allowing non-forested and forested ecosystem dynamics to be compared. This paper examines palaeoecological and archaeological data from a lowland open savanna site situated on the south-central PNG coastline. The methods used incorporate pollen and micro-charcoal analyses, artefact recovery and sediment descriptions. We conclude with an environmental model of sedimentation and vegetation change for the past c. 5,800 years, revealing a mid to late Holocene savanna interchange between herbaceous and woody plant growth, with fluctuating fire occurrence increasing toward the present day. Increased silt deposition and modified regional hydrology are also recorded. Environmental changes correspond in timing with the start of permanent settlements and human use of fire. In particular, landscape burning for hunting and gardens for agriculture have helped create the open ecosystem still evident today.
\end{abstract}

\title{
Keywords
}

Papua New Guinea; lowland; savannah; Holocene; palaeoecology; archaeology 


\section{Introduction}

In browsing travel guides and tourist brochures, Papua New Guinea (PNG) is variously described as 'endless greenery' (Lonely Planet 2017, p 1) and 'an isolated and incredibly rugged Garden of Eden' (Duckett 2016, p 1). In popular reputation PNG is a forested place; indeed, dense tropical rainforests are an extensive and integral part of its landscapes and biodiversity. Closed tropical forests (upper and lower montane, lowland), swamp forests and mangrove forests provide floral/faunal habitats and (non-)timber products, hold cultural and aesthetic value, while also playing major environmental service roles such as the cycling of water and carbon dioxide (Shearman et al. 2008; Shearman and Bryan 2011). However, a third of PNG's land area is not forested, encompassing cover such as scrub, swamp grassland and the grassland-savanna-woodland spectrum. These environments also contribute to the country's ecology, society and economy, adding to its wealth of biological diversity and all manner of natural resources that sustain human populations, past into present (Shearman et al. 2008; Gressit 2012).

Biogeographical compilations divide PNG into a series of ecoregions, whose boundaries can be sharp and encompass areas within which certain ecological and evolutionary processes most strongly interact (Takeuchi 2007). For Olsen et al. (2001), PNG ecoregions are separated on the basis of biological characteristics, palaeoenvironments and local opinion. For Shearman and Byran (2011), biogeographical divisions incorporate the geological history of accretion, temperature and rainfall domain, as well as floral mapping. In each case the southern PNG lowlands are classed as biogeographically distinct from northern drainage basins, mountainous ranges and island groups, for example, and it is throughout this area that extensive and complex tracts of savanna vegetation exist.

Tropical savannas exhibit marked variability in space and time. Bourlière and Hadley (1983, p 12) suggest that this variability is their most important feature and state that 'there is no such thing as a typical savanna ecosystem, rather a gradient of related ecosystems ranging from open woodland to almost treeless plains'. In short, 'savanna' incorporates a number of structural and floristic complexes. Paijmans (1975) and Blake et al. (2010) mapped the savannas of PNG, demonstrating large-scale coverage from the southwest (Trans-Fly lowland plains) to sub-coastal areas east of Port Moresby. The vegetation has been described in detail by Gillison (1983), Paijmans (1976) and Clunie (1995), and classified as either eucalypt savanna, Melaleuca savanna and/or mixed savanna.

PNG savannas show strong structural and floristic relationships with northern Australia (Gillison 1983). They are remnants of a once wider, now relict, Sahul geographic range, and date from the past two glacial periods (Nix and Kalma 1972; van der Kaars 1991). The presence of savanna during the last two glacial maxima is of importance to understanding the environmental contexts of human presence and colonisation; evidence of the Sunda-Sahul shelves, areas of shallow sea which may have been dry land at various times and thus providing a savanna corridor, has been used to explain the dispersal of early humans from mainland southeast Asia to Java, onward to eastern Indonesia, PNG and then to Australia (Jones 1980; Jones and Bowler 1980; Bird et al. 2005, 2016, 2018; Slik et al. 2011). The southern PNG lowlands were also the setting for more recent Austronesian expansions and colonisation processes into Melanesia, notably associated with Lapita peoples of the past c. 3,300 years (for example, McNiven et al. 2011, 2012). Holocene savanna landscapes are playing a large part in archaeological discussions ranging from interpretations of local patterns and trends (McNiven et al. 2012; Skelly et al. 2014) to explorations of the southern PNG coast as a socially networked space (David et al. 2016a; digim'Rina et al. 2016). It is also increasingly recognised that the low altitude land in PNG is diminishing and/or degrading under modern population pressures, from 
urbanization, industrial development and agricultural expansion (Samanta and Pal 2016). Notably for the savanna, fire caused by human agencies is currently preventing or inhibiting tree regeneration, causing a change toward open grassland, amplified when burning coincides with shifting local cultivation (Eden 1993; Shearman et al. 2008).

Far less palaeoecological research has been carried out in the non forested compared to forested zones of PNG. Ridpath (1985) warns of dangers in the transfer of ideas regarding rates and directions of vegetation change from one ecosystem to another, and in the same way Fairhead and Leach (1996) talk of misreading landscapes in the context of African savannas. Most palaeoecological studies in PNG have been based on the highlands (for instance, Haberle 1998; Haberle et al. 2012). Broad statements on savanna palaeoecology can be found (see reviews by Hope 2007, 2009) and indications of lowland mainland vegetation have been inferred from New Guinea islands (for example, Prebble et al. 2010; for discussions drawn from the Aru islands of northern Sahul, see Hope and Aplin 2005). In a review of 50 New Guinea palynology studies, Haberle (2013) noted a predominance of sites at more than 1,200-1,450 m a.s.l., with very few investigations undertaken in the lowlands of New Guinea as a whole. In two rare lowland pollen studies, Osborne et al. (1993) and Rowe et al. (2013) observed the same. McNiven et al. (2010) comment on the situation from an archaeological viewpoint.

Here we suggest that a greater focus on long-term lowland environmental studies can enable better understanding and promotion of the significance of regional savannas. In turn, we suggest that this focus should incorporate experimentation into the types of sites used to gain palaeoecological records, particularly in areas lacking traditional lake sediments. We present a discussion specifically targeting PNG savanna and provide a level of palaeoecological detail not previously available for non forested PNG. This enables us to tease out the finer nuances of composition and long-term change within a savanna environment.

\section{Environment}

Caution Bay is located $25 \mathrm{~km}$ northwest of Port Moresby in the Central Province of PNG (Fig. 1). It is one of a series of bays along the PNG south-central coast, with a shallow coastal basin containing an outer barrier reef as well as a near shore fringing reef, protected shoreline and two major estuaries. Moving inland, a sequence of environmental zones runs parallel to the coast, comprising a shoreline system merging with alluvial plains into a coastal hinterland, with coastal lowland and hill ridge combination merging into the mountains of the Owen Stanley range. These environmental zones correspond to the Papa, Boroko and Fairfax land systems respectively, as mapped and described by Mabbutt et al. (1965). Long-term climate statistics are available from Port Moresby (BoM 2017). This central-southern PNG region has a tropical savanna climate (Köppen-Geiger's subtype Aw, Peel et al. 2007), characterized by high year-round temperatures and high but strongly seasonal rainfall. Seasonality is dictated by the interplay between regional monsoonal systems with a December-April wet season and south-east trade winds giving a June-October dry season. El Niño-Southern Oscillation (ENSO) phases in turn influence the start and strength of the monsoon. Tropical cyclones are rare in this part of PNG (Sturman and Tapper 2005). 


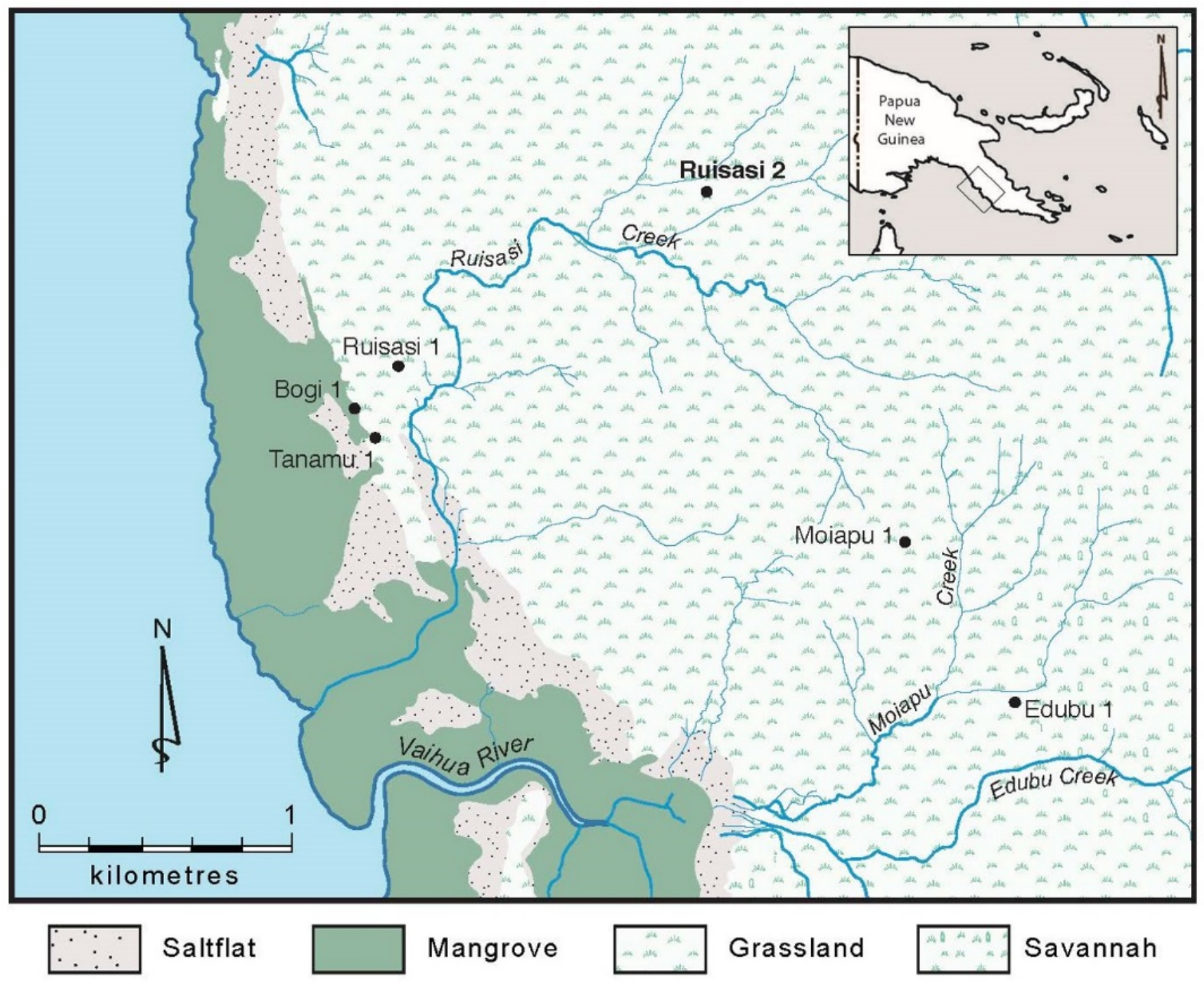

Figure 1. Caution Bay study area showing locations of Ruisasi 2 and previously published archaeological excavations (summarized in David et al. 2016b). Inset shows the position of Caution Bay on the southern Papua New Guinea coastline. 
Ruisasi 2 (PNG National Museum and Art Gallery site code AAIJ) is an open site with sparse archaeological deposits (David et al. 2016b). Palaeoecological examination of the sediments provides a previously unavailable inland environmental context for the archaeological sequence, as well as an alluvial plain complement to the Caution Bay late Holocene littoral plains vegetation study of Rowe et al. (2013).

Ruisasi 2 is located $900 \mathrm{~m}$ inland from the open coast. It is positioned within Caution Bay's coastal hill zone lowlands, on an open alluvial plain. The site is gently undulating in an area that incorporates wide, illdefined and shallow watercourses, where prolonged wet season flooding encourages temporary marsh-like wetland formation (Fig. 2). The alluvial plain slopes to merge with a littoral plain. Ruisasi 2 is $5 \mathrm{~m}$ a.s.1., 200 $\mathrm{m}$ east of the transition between the alluvial plain and the littoral plain, a boundary marked by a series of exposed sand dunes.

Local site vegetation consists of mixed grassland plants (Ophiuros, Imperata, Themeda), becoming irregular and noticeably tussocked in lower-lying depressions and/or poorly drained areas. Woody taxa form irregularly spaced, moderately dense woodland patches, their structure and floristics varying with local relief and drainage conditions, the frequency of burning also being an influence. The most common trees are species of Pandanus, accompanied by low-branched evergreen taxa such as Nauclea, Alstonia, Ficus, Sterculia, Terminalia and Bombax (Fig. 2). Woodland patches are surrounded more broadly by open Eucalyptus savanna communities with E. alba, E. papuana and Themeda australis. Littoral zone open tidal mudflats and intertidal mangrove forest are occupied by species of Avicennia at the landward margin and Rhizophora towards the sea. The mangroves are up to $450 \mathrm{~m}$ wide at the nearest point to Ruisasi 2.

Today there are four villages in the Caution Bay catchment, Kido, Boera, Papa and Lea Lea. Also, the village of Porebada is near to Ruisasi creek (Fig. 1), but outside Caution Bay. The Ruisasi 2 site area forms part of a wider hunting, fishing, burning and agricultural (subsistence and cash-cropping) land use zone for members of each of these four communities. Commercial cattle raising was undertaken during parts of the 20th century, but not today (McNiven et al. 2012; digim'Rina et al. 2016)

\section{Methods}

Ruisasi 2 is a small $(<25 \mathrm{~m} 2)$, low-density surface scatter of stone artefacts and cultural shell remains (David et al. 2009, 2016b). A $1 \times 1 \mathrm{~m}$ square was archaeologically excavated. Excavation units (XU) averaging $2 \mathrm{~cm}$ in thickness followed the stratigraphy, with excavation proceeding down to culturally sterile sediments.

Cultural finds over $2 \mathrm{~cm}$ in length, including marine shell, stone artefacts, pottery sherds, vertebrate remains and selected charcoal samples, were plotted in situ in three dimensions during excavation, then individually bagged. Bulk sediment samples were also collected from each XU and subsequently 5 gm per XU was subsampled for pollen and charcoal analyses. All other excavated sediments from each XU were weighed, wetsieved with a $2.1 \mathrm{~mm}$ mesh, air-dried in the field and subsequently sorted in the laboratory. On completion of the excavation, the walls of the excavation square were photographed and these sections drawn. 

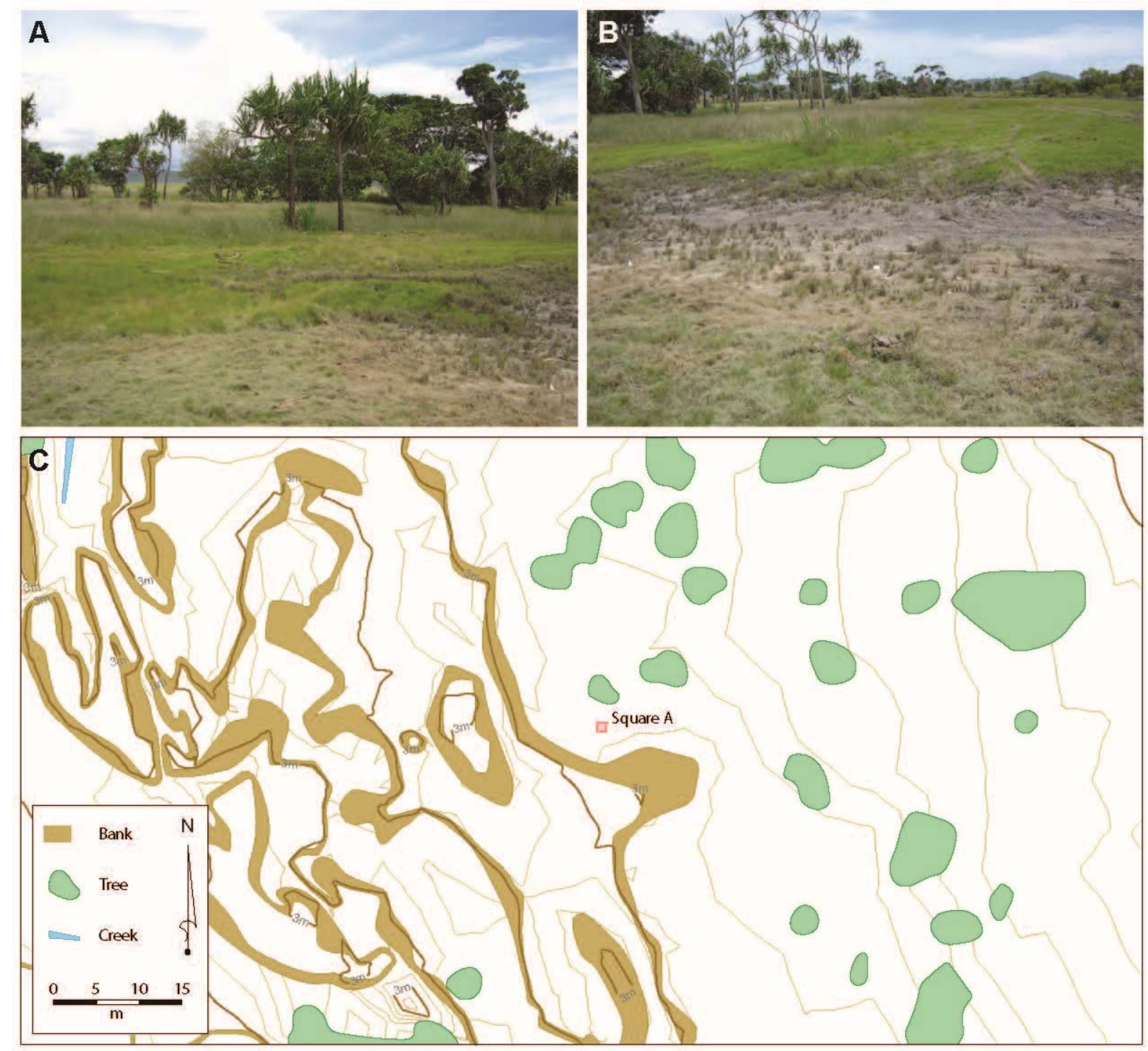

Figure 2. Ruisasi 2 local ecology; a, facing east; b, towards southeast; c, mapping in overview (photos by Laura Bates). 
Hall (1990) and Davis (1994) discuss soil pollen analysis, including aspects of archaeological palynology. Both authors provide interpretative guidelines on how pollen analysis of soils differs from that traditionally done on stratified waterlogged deposits. Laboratory processing of pollen and charcoal samples followed standard late Quaternary techniques as outlined by Brown (2008), selected to first disperse and then progressively remove humic acids, calcium carbonates, bulk organics, cellulose and silicates, by using treatments including with $\mathrm{Na} 4 \mathrm{P} 2 \mathrm{O} 7, \mathrm{KOH}, \mathrm{HCl}$, acetolysis, $\mathrm{HF}$ and $\mathrm{C} 2 \mathrm{H} 5 \mathrm{OH}$ washes. A Lycopodium spike was added to the samples to enable calculation of relative concentrations of both pollen and charcoal. Microscopic charcoal was counted in the pollen preparations and defined as fragments of angular form, black, opaque and between 10 and $125 \mu \mathrm{m}$ in length. The charcoal record is considered to be a proxy for local to regional burning within the catchment (Whitlock et al. 2010).

Pollen identification was assisted by reference collections held at Monash University's School of Geography and Environmental Science, on-site floral collections, previously published palaeoecological studies from within PNG (such as Garrett-Jones 1979) and online photographic sources (APSA Members 2007). For data presentation the Tilia suite of programs was used (spreadsheet application Tilia 1.7.4 and graphing counterpart TGView 2.0.2, Grimm 1991). CONISS provided a stratigraphically constrained cluster analysis for numerical zonation to enhance correlation of microfossil data (Grimm 1987). Pollen and spore counts are expressed as total pollen percentages, calculated from a pollen sum up to 220 grains.

Six charcoal and shell samples were submitted to the Waikato radiocarbon dating laboratory, New Zealand for AMS radiocarbon dating (Waikato Radiocarbon Dating Laboratory 2017).

Radiocarbon dates were calibrated using OxCal 4.3 (Bronk Ramsey 2009). Shell samples were calibrated using the Marine13 calibration dataset (Reimer et al. 2013), with a $\Delta \mathrm{R}$ of $13 \pm 1614 \mathrm{C}$ years for Conomurex luhuanus (Petchey et al. 2012), 11 \pm 17 14C years for Conus sp., after the value for local Echinoidea (sea urchins etc.) as fully marine taxa (Petchey et al. 2013) and -71 $1514 \mathrm{C}$ years for Ostreidae, after the value for local Anadara granosa as a mid intertidal to marginally subtidal taxon (Petchey et al. 2013). Specific R values for local Conus sp. and Ostreidae are not available, but Conus sp. tends to be fully marine (as reflected in $\delta 13 \mathrm{C}=1.0 \%$ ), while the oyster $\delta 13 \mathrm{C}=-2.2 \%$ suggests some riverine/terrestrial input. Charcoal samples were calibrated with the IntCal13 dataset (Reimer et al. 2013).

\section{Results}

\subsection{Stratigraphy and Dating}

Excavation was undertaken in $17 \mathrm{XUs}$ to a maximum depth of $45 \mathrm{~cm}(44.9 \mathrm{~cm})$ below the ground surface. Two stratigraphic units (SUs) were identified. The sediments were dominated by clay but included sand, minor silts and organic material. The organic content decreased, but clay compaction, as well as sand, increased with depth. An upper unit (SU1) of dark brown-grey peaty clay overlay pale grey, mottled (orange) sandy to heavy clay (SU2). The interfaces between the SUs occurred over 5-20 mm. Fine cracks (horizontal and diagonal) were present within the peaty clay, although root penetration and gravel content were minor. Changes in soil colour were the distinguishing horizon feature, as opposed to changes in soil texture or in soil structural size and/or shape. The pale grey colour of SU2 suggested that the site was poorly drained, due to low permeability. Colour mottles are also commonly associated with poorly drained soils that become seasonally wet (McDonald et al. 1998). 
Age determinations are presented in Table 1 and indicate that the near-basal XU14-XU15 sediments (33.8$37.1 \mathrm{~cm})$ were deposited c. 5,000-5,400 BP (5,750-6,300 cal BP) The slight reversal in age between samples Wk-30017 and Wk-30018 is attributed to the changing drainage conditions outlined in the discussion, and so Wk-30017 is not included in the interpretation.

\subsection{Excavated Materials}

Table 2 lists the excavated materials by excavation unit. Cultural materials were largely limited to flaked stone artefacts. Minor amounts of marine shell were also present. No pottery sherds were present. XU1, $\mathrm{XU} 4, \mathrm{XU} 8, \mathrm{XU} 16$ and XU17 were culturally sterile, but all other XUs contained at least one cultural item, albeit usually as very small fragments.

A total of eight stone artefacts with a total weight of $1.0 \mathrm{~g}$ were recovered. All of these were made of chert, a common local raw material found from the coast to the foothills (Davies and Smith 1971). They were small, averaging $6.3 \mathrm{~mm}$ and ranging between $3 \mathrm{~mm}$ and $14 \mathrm{~mm}$ in maximum length. Their weights ranged from $0.01 \mathrm{~g}$ to $0.81 \mathrm{~g}$, with a mean of $0.15 \mathrm{~g}$. They were all made by unipolar (freehand) percussion and consisted of flaked pieces $(62.5 \%, \mathrm{n}=5)$ and unretouched broken flakes $(37.5 \%, \mathrm{n}=3)$. Table 2 also presents information on fracture type distributions and weights by XU. These results indicate that on-site stone tool making was rare.

Shell was present in XU2, XU3, XU5-XU11 and XU13 (Table 2). The total shell weight was $5.1 \mathrm{~g}$ (NISP = $5, \mathrm{MNI}=3$ ). The assemblage contained $3.5 \mathrm{~g}$ of marine gastropods ( $\mathrm{NISP}=3, \mathrm{MNI}=1,68 \%$ by weight) and $0.4 \mathrm{~g}$ of marine bivalves (NISP $=1, \mathrm{MNI}=1,8.5 \%$ ). A small amount of fragmented freshwater gastropod was also found $(0.04 \mathrm{~g}, \mathrm{NISP}=1, \mathrm{MNI}=1)$.

Due to the small and weathered nature of the fragments, $1.2 \mathrm{~g}(23.0 \%)$ of the shell could not be identified. Conus sp. (1.9 g, 37\%) and Conomurex luhuanus (1.6 g, 31\%) dominate the identified shell. Both taxa occupy multiple habitats, spanning coral reef flats, shallow sandy seafloors, seagrass beds and/or tidal mudflats. Ellobiidae and Ostreidae taxa occur in mangrove environments, the former extending into freshwater, the latter into intertidal rocky zones (Aplin et al. 2016).

\subsection{Pollen and Microcharcoal}

The Ruisasi 2 pollen and microcharcoal diagram is presented in Fig. 3. The pollen and spore results have been divided at XU6 (14.7 cm, c. $290 \mathrm{cal} \mathrm{BP})$ into two major zones with subzones. This division is determined largely by variations in Pandanus and Poaceae. Secondary influences on the zonation are a difference in Pteridophyta (ferns) and Cyperaceae (sedges), as well as a change in the type of herbaceous flora represented. The two major zones are also marked by a significant difference in pollen and charcoal concentrations. 
Table 1. AMS radiocarbon age determinations for Ruisasi 2, Square A. * = date may extend out of range, therefore modern.

\begin{tabular}{|c|c|c|c|c|c|c|c|c|c|c|c|}
\hline $\begin{array}{l}\text { Sample } \\
\text { Code }\end{array}$ & SU & $\mathbf{X U}$ & $\begin{array}{l}\text { Depth } \\
\text { (cm) }\end{array}$ & Material Dated & $\begin{array}{l}\text { Weight } \\
\text { (g) }\end{array}$ & $\begin{array}{c}\text { pMC } \\
(\%)\end{array}$ & $\begin{array}{c}\delta^{13} \mathrm{C}(\%) \\
\quad \pm 0.2\end{array}$ & $\begin{array}{l}{ }^{14} \mathrm{C} \text { Date } \\
\pm 1 \sigma(\mathrm{BP})\end{array}$ & $\Delta \mathbf{R}$ & $\begin{array}{c}\text { Calibrated } \\
\text { Age } \pm 95 \% \\
\text { probability } \\
\text { (cal BP) }\end{array}$ & $\begin{array}{l}\text { Calibrated Age } \\
\text { BP (median } \\
\text { probability) }\end{array}$ \\
\hline Wk-38680 & 1 & 2 & $1.1-3.0$ & $\begin{array}{l}\text { Sieved Conus sp. } \\
\text { shell }\end{array}$ & 0.30 & 93.1 & 1.0 & $578 \pm 24$ & $11 \pm 17$ & $282-112^{*}$ & 203 \\
\hline Wk-38681 & 1 & 3 & $3.0-6.0$ & $\begin{array}{c}\text { Sieved } \\
\text { Conomurex } \\
\text { luhuanus shell }\end{array}$ & 0.16 & 93.0 & 1.4 & $580 \pm 23$ & $13 \pm 16$ & $281-117^{*}$ & 203 \\
\hline Wk-38683 & 1 & 7 & $14.7-17.4$ & $\begin{array}{c}\text { Sieved } \\
\text { Conomurex } \\
\text { luhuanus shell }\end{array}$ & 0.15 & 92.7 & 1.3 & $613 \pm 25$ & $13 \pm 16$ & $301-137$ & 249 \\
\hline Wk-38684 & 1 & 10 & $22.9-25.8$ & $\begin{array}{l}\text { Sieved Ostreidae } \\
\text { sp. shell }\end{array}$ & 0.05 & 70.9 & -2.2 & $2766 \pm 26$ & $-1 \pm 16$ & $2648-2360$ & 2497 \\
\hline Wk-30017 & 2 & 14 & 33.8 & $\begin{array}{l}\text { In-situ charcoal } \\
\text { fragment }\end{array}$ & 0.31 & 50.9 & $\begin{array}{c}\text { Not } \\
\text { available }\end{array}$ & $5432 \pm 30$ & NA & $6291-6193$ & 6240 \\
\hline Wk-30018 & 2 & 15 & 37.1 & $\begin{array}{l}\text { In-situ charcoal } \\
\text { fragment }\end{array}$ & 0.63 & 53.1 & -25.8 & $5085 \pm 30$ & NA & $5911-5747$ & 5813 \\
\hline
\end{tabular}


Table 2. Archaeological find summary of Ruisasi 2, Square A: excavated materials and chert fracture type by excavation unit (XU), with numbers of individual specimens (NISP), minimum numbers of individuals (MNI) and weights for all shell taxa.

\begin{tabular}{|c|c|c|c|c|c|c|c|c|c|c|c|c|c|c|c|c|c|c|}
\hline \multirow[t]{2}{*}{$\mathbf{X U}$} & \multirow{2}{*}{$\begin{array}{l}\text { Mean } \\
\text { thickness } \\
\text { of XU } \\
\text { (cm) }\end{array}$} & \multirow[t]{2}{*}{$\begin{array}{l}\text { Excavated } \\
\operatorname{area}\left(\mathbf{m}^{2}\right)\end{array}$} & \multirow{2}{*}{$\begin{array}{c}\text { Charcoal } \\
\text { (g) }\end{array}$} & \multirow{2}{*}{$\begin{array}{c}\text { Marine } \\
\text { shell } \\
(g)\end{array}$} & \multirow{2}{*}{$\begin{array}{c}\text { Land } \\
\text { snail } \\
(\mathrm{g})\end{array}$} & \multirow[t]{2}{*}{$\begin{array}{c}\text { Gravel } \\
\text { (g) }\end{array}$} & \multirow{2}{*}{$\begin{array}{c}\text { Flaked } \\
\text { stone } \\
\text { artefacts } \\
(\#)\end{array}$} & \multirow{2}{*}{$\begin{array}{l}\text { Flaked } \\
\text { stone } \\
\text { artefacts } \\
\quad(\mathrm{g})\end{array}$} & \multicolumn{2}{|c|}{$\begin{array}{c}\text { Chert: } \\
\text { broken } \\
\text { flake } \\
\text { other }\end{array}$} & \multicolumn{2}{|c|}{$\begin{array}{c}\text { Chert: } \\
\text { flaked piece }\end{array}$} & \multicolumn{2}{|c|}{ Chert total } & \multicolumn{4}{|c|}{ Shell taxa } \\
\hline & & & & & & & & & g & $\#$ & g & g & $\#$ & g & Taxon & NISP & MNI & $\begin{array}{l}\text { Weight } \\
\text { (g) }\end{array}$ \\
\hline 1 & 1.1 & 1.00 & & & & & & & & & & & & & & & & \\
\hline 2 & 1.9 & 1.00 & & 1.89 & & & & & & & & & & & Conus sp. & 1 & 1 & 1.89 \\
\hline 3 & 3 & 1.00 & & 0.17 & & & & & & & & & & & $\begin{array}{c}\text { Conomurex } \\
\text { luhuanus } \\
\text { Unidentified }\end{array}$ & 1 & & $\begin{array}{l}0.16 \\
0.01\end{array}$ \\
\hline 4 & 3 & 1.00 & & & 0.02 & & & & & & & & & & & & & \\
\hline 5 & 2.8 & 1.00 & & 0.52 & & 0.16 & & & & & & & & & $\begin{array}{l}\text { Conomurex } \\
\text { luhuanus } \\
\text { Unidentified }\end{array}$ & & & $\begin{array}{l}0.24 \\
0.28\end{array}$ \\
\hline 6 & 2.9 & 1.00 & & 0.26 & & & & & & & & & & & & & & \\
\hline 7 & 2.7 & 1.00 & & 1.82 & & 0.03 & 1 & 0.03 & & & 1 & $<0.1$ & 1 & $<0.1$ & $\begin{array}{c}\text { Conomurex } \\
\text { luhuanus } \\
\text { Ellobiidae sp } \\
\text { Ostreidae sp. } \\
\text { Unidentified }\end{array}$ & $\begin{array}{l}1 \\
1 \\
1\end{array}$ & $\begin{array}{l}1 \\
1\end{array}$ & $\begin{array}{l}1.18 \\
0.04 \\
0.38\end{array}$ \\
\hline 8 & 2.8 & 1.00 & & 0.02 & & & & & & & & & & & Unidentified & & & 0.02 \\
\hline 9 & 2.7 & 1.00 & & 0.20 & & 0.01 & 1 & 0.05 & & & 1 & $<0.1$ & 1 & $<0.1$ & Unidentified & & & 0.20 \\
\hline 10 & 2.9 & 1.00 & & 0.16 & & 0.68 & 1 & 0.02 & & & 1 & $<0.1$ & 1 & $<0.1$ & $\begin{array}{l}\text { Ostreidae sp. } \\
\text { Unidentified }\end{array}$ & & & $\begin{array}{l}0.06 \\
0.10\end{array}$ \\
\hline 11 & 2.6 & 1.00 & & 0.04 & & 0.32 & 1 & 0.81 & 1 & 0.8 & & & 1 & 0.8 & Unidentified & & & 0.04 \\
\hline
\end{tabular}




\begin{tabular}{|c|c|c|c|c|c|c|c|c|c|c|c|c|c|c|c|c|c|c|}
\hline 13 & 2.4 & 1.00 & & 0.06 & & 0.05 & & & & & & & & & Unidentified & & & 0.06 \\
\hline 14 & 2.5 & 1.00 & 0.31 & & & & & & & & & & & & & & & \\
\hline 15 & 2.6 & 0.25 & 0.63 & & & 0.04 & 2 & 0.09 & 2 & 0.1 & & & 2 & 0.1 & & & & \\
\hline 16 & 3 & 0.25 & & & & 0.06 & & & & & & & & & & & & \\
\hline 17 & 3 & 0.25 & & & & & & & & & & & & & & & & \\
\hline Total & - & - & 0.94 & 5.14 & 0.02 & 1.36 & 8 & 1.03 & 3 & 0.9 & 5 & 0.1 & 8 & 1.0 & & 5 & 3 & 5.14 \\
\hline
\end{tabular}




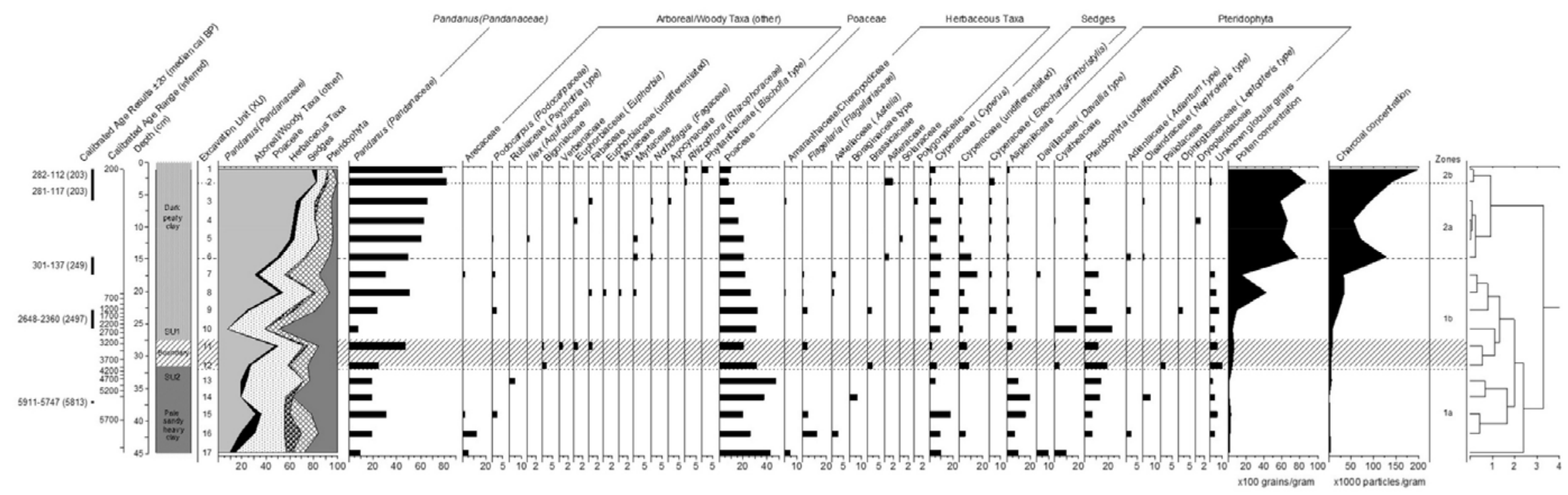

Figure 3. Pollen and microcharcoal diagram for Caution Bay Ruisasi 2, showing pollen percentages of total pollen sum and microcharcoal concentrations/gm plotted against depth, stratigraphy, excavation unit and calibrated radiocarbon age. 


\subsubsection{Zone 1 (SU2, XU17-XU6, 45-14.7 cm, >5,800-290 cal BP)}

All non-woody taxa are best represented in Zone 1. The lowermost Zone 1a (>5,800 to c. 4,500 cal BP) is characterised by relatively uniform plant group values. This uniformity declines into Zone 1b (c. 4,500-290 cal BP), characterised by the strongest degree of plant group fluctuation amongst all samples. The herbaceous association is dominated by Poaceae, with peak values in XU17 and XU13 (43\%), with an overall shifting decline in abundance toward the top of the zone (20\%). Minor herbaceous taxa (Chenopodiaceae, Asteliaceae-Astelia-type, Brassicaceae and Boraginaceae) are scattered in their distributions (up to $11 \%$, with a notable XU16 peak in Flagellaria-Flagellariaceae). The Cyperaceae group is dominated by Cyperus and Eleocharis/Fimbristylis is introduced to the record from XU9. The Cyperaceae momentarily disappear from the record at XU14 but are otherwise consistently present (10-15\%). Fern values are highest for the entire record in XU10 (c. 2,500 cal BP, 46\% peak), showing a strong signal from Aspleniaceae, Cyatheaceae and undifferentiated Pteridophyta types, and lower occurrence of Davalliaceae (Davallia-type), Adiantaceae, Oleandraceae (Nephrolepis-type), Psilotaceae and Ophioglossaceae (Leptopteris-type). The ferns show a similar distribution trend to Poaceae and decline to $16 \%$ toward the top of Zone 1.

Zone 1 woody taxa are dominated by Pandanus with varying values (7-50\%), and the significant Pandanus decline at XU10 is largely a response function to fern percentages; if the Pteridophyta were removed from the pollen sum as local taxa, Pandanus would be expected to gradually rise through Zone 1, in counter-trend to Poaceae, which would fall (Smol et al. 2001). The few other woody taxa show low percentages, with many occurring once or infrequently (Podocarpus-Podocarpaceae, Rubiaceae-Psychotria-type, Bignoniaceae, Verbenaceae, Euphorbiaceae-Euphorbia, undifferentiated Moraceae and Myrtaceae; woody taxon diversity is greater in Zone 1b). Relatively high values of Arecaceae occur in Zone 1a (11\%). Pollen and charcoal concentrations remain low in Zone 1 until XU11-XU10 (c. 3,000-2,500 cal BP), the pollen rising and falling more substantially at the top of the zone.

\subsubsection{Zone 2 (SU2, XU6 to surface, $14.7-0 \mathrm{~cm}$, c. $290-0$ cal BP)}

In Zone 2 woody taxa predominate over non-woody ones, and this zone demonstrates reduced plant group fluctuations. It is divided into Zone 2a (c. 290-200 cal BP) which is characterised by steadily increasing Pandanus values, while in Zone $2 \mathrm{~b}$ (c. 200-0 cal BP) this Pandanus increase ceases and along with most other taxa, values are maintained at a consistent level and/or decline slightly toward the surface. In Zone 2a Pandanus abundance rises from 50\% to $81 \%$ (XU6-XU3). This rise is not paralleled by increased values in other woody taxa. There are rather low and irregular appearances of Arecaceae, Podocarpus (Podocarpaceae), Ilex (Aquifoliaceae), Euphorbiaceae (Euphorbia), Fabaceae, Myrtaceae and Nothofagus (Fagaceae). In addition, taxa from the Rubiaceae, Bignoniaceae, Moraceae and Euphorbiaceae are no longer recorded. The mangrove taxon Rhizophora is limited to Zone $2 \mathrm{~b}$. The herbaceous signal is noticeably less diverse. Poaceae values are initially stable across XU6-XU5 (20\%) but decline toward the surface (9\%). Secondary herbaceous taxa are dominated by Asteraceae, with smaller amounts of Solanaceae and Polygonaceae. Total Cyperaceae are at their highest across the Zone 1-2 boundary (20-25\%) but decrease to $5 \%$ within Zone 2b. Cyperus remains the principle sedge. Of the non-woody taxa, the Pteridophyta show the most dramatic decline. All ferns show low abundance and demonstrate a slight shift in taxon representation (Aspleniaceae, Cyatheaceae, Adiantaceae, Oleandraceae-Nephrolepis-type; Dryopteridaceae is added to the record in Zone 2, whereas Psilotaceae and Ophioglossaceae-Leptopteris-types are no longer recorded). Zone 2 incorporates an initial sharp jump in pollen and charcoal concentrations, which decline mid-way through the zone. Towards the surface, charcoal shows a marked rise, but pollen concentrations decline slightly. 


\section{Discussion and Conclusions}

Ruisasi 2 contains sparse archaeological materials indicating low intensity indirect human activity after some time between 3,000-2,500 cal BP. In the wider area, the archaeological record for Caution Bay begins close to 6,000 cal BP at Tanamu 1 and contains periodic cultural deposits with marine resources, especially shell but also Dugong dugon (dugong) and marine turtle bones, as well as inland (terrestrial) vertebrate taxa. Pottery in the form of Lapita culture wares first arrives c. 2,900 cal BP at Bogi 1 and other nearby sites, in newly established coastal settlements, followed soon after (especially c. 2,700 cal BP) by the establishment of more inland low hilltop villages that also contain pottery sherds, such as Moiapu 1 . This phase of village establishment, associated with the arrival of pottery, corresponds well with the timing of SU2 deposition at Ruisasi 2, suggesting cultural deposition and indicating sustained and widespread human populations across the Caution Bay landscape from that time. The coastal Lapita villages were extensive and changed their locations slightly, both within and through the transition from Lapita to post-Lapita times. Many archaeological sites show particularly intensive occupation c. 2,200-2,000 cal BP. Around 2,000 cal BP the Caution Bay villages ceased to be occupied, with the emergence of rare and short-lived new village locations after 2,000 cal BP. However, cultural materials continued to be deposited across the Caution Bay landscape at all times after 2,000 years ago, presumably by residents of newly established nearby villages. The shift in village locations from Caution Bay to nearby areas is thought to be associated with the development of dense mangrove habitats along the Caution Bay shoreline c. 2,000 yr BP (Rowe et al. 2013), reducing access to beaches (for mooring of boats) and reefs (for food and other resources) in the process. It is likely that the current nearby village of Boera (where mangroves have not developed to inhibit direct access to the sea) was established, or grew, at this time, as Caution Bay villagers moved to new regional settlements. A final phase of intensive archaeological deposition is again evident during the last 300 to 400 years before the start of the 19th century and European colonisation. This is in association with a phase of maritime exchanges ethnographically known as the hiri, for which specialised pottery was made in the village of Boera, at the eastern end of Caution Bay (for a detailed description of the hiri, see Skelly and David 2017). Archaeological research at Boera has not yet been undertaken (unpublished data in author's possession).

Figure 3 illustrates a number of different plant associations within the Ruisasi 2 area from the mid Holocene to modern. This covers the known period of human occupation as revealed by the Caution Bay archaeological record investigated so far, as mentioned above. Trees (canopy and sub-canopy), shrubs, herbs (forbs and graminoids), climbers, grasses and sedges are represented in the pollen and spores. These plant types demonstrate evergreen and deciduous, sclerophyll (hard leaved) and malacophyll (soft broadleaved) characters. They are also known occupants of habitats such as savanna, littoral thicket, secondary dry or monsoonal forest and seasonal swamps. However, rather than indicating alternating multiple habitats across the Ruisasi 2 area from the mid Holocene to present, the pollen results reflect a more changing structure and floristics within an ongoing mixed savanna, that is a mixed savanna which has been variously modified, not periodically replaced or extensively destroyed. This is in line with Gillison (1983, p 217), who described New Guinea savanna as a 'complex'. Two phases of largely single type vegetation (Zones 1a and 2a, >5,8004,500 and 290-200 cal BP respectively) are separated by sediment changes and an episode of greater variation and intermingling of vegetation (Zone 1b, c. 4,500-290 cal BP). Change within the modern period is represented in the uppermost samples (Zone 2b, <200 years) (Fig. 3).

Pandanus and the Pteridophyta play key roles in understanding the Ruisasi 2 pollen sequence. They indicate that over the long term, Ruisasi 2 was an area where vegetation was able to obtain a moderate or small amount of water, potentially including through the dry season. They also indicate site disturbance.

Conversely, some Ruisasi 2 pollen types are excluded from the consideration of local plant communities due 
to their long-distance transport into the Ruisasi 2 environment. Nothofagus (Fagaceae) is known to occur at between 600 and 3,100 m, and assumes forest canopy dominance mainly between 1,300 and 3,000 m.

Podocarpus (Podocarpaceae) is not necessarily restricted to the PNG highlands, but in areas above 2,400 m conifers, including Podocarpus, tend to dominate the canopy and emergent tree layers. Rhizophora (Rhizophoraceae) is a mangrove taxon known to occupy regularly submerged intertidal zones (including the current coastline), with a reputation for highly anemophilous (wind dispersed) pollen (Paijmans 1976; Conn and Damas 2006; Rowe 2012).

On the continental island of New Guinea, Pandanus is typically found in eucalypt savanna, concentrated along moist gullies or in depressions. Similarly, but more notably, Pandanus species also form part of the sedge-grassland vegetation on poorly drained coastal and inland plains in this monsoonal region. These plains are dry in the dry season but inundated in the wet season because of the heavy, impermeable clay soils and poor surface runoff (Paijmans 1976; Conn and Damas 2006), as in the current Ruisasi 2 landscape. Accordingly, in palaeoecology Pandanus is viewed as both a seasonal swamp and also as a savanna taxon (Hope and Aplin 2005; for implications on the study of early agriculture in highland New Guinea, see Haberle 1995). High representation of Pandanus in Holocene pollen records from the Indo-Pacific is variously interpreted as a marker of disturbed environments, as a disturbance opportunist (Anshari et al. 2001) and also as a tree tolerant of prevalent fire (see Haberle 1995 for New Guinea; Hope and Aplin 2005 for the Aru islands; Rowe 2012; Prebble et al. 2005 and Shulmeister 1992 for northern Australia).

Holocene records in areas such as Micronesia (for example, Phear 2008) also consider ferns (and fern allies) as environmental disturbance indicators when recorded in savanna contexts. Phear (2008, pp 309, 318) makes a distinction between tropical savanna dominated by Pandanus and grasses, and savannas incorporating an undergrowth of ferns, describing the former as 'classic savanna grassland' and the latter as indicative of a 'disturbed vegetation pattern'. While different ferns tolerate various scales of disturbance including different climatic conditions, all ferns require liquid water during their development from spores to full plants, and so they are moisture sensitive for part of their life cycles (Jones and Clemesha 1978). In modern vegetation classifications and in studies into controls of plant abundance and distributions in monsoonal northern Australia, associations between soil moisture gradients and the cover of ferns and also palms have been documented (Bowman et al. 1991). Ferns are also intolerant of repetitive fire (Jones and Clemesha 1978). For example, within PNG, where regular annual burning is discontinued within the lowland alluvial plain environment, grass layers are gradually shaded out and replaced by other plant types such as ferns (Eden 1974; Paijmans 1976). A general mosaic of broadleaf secondary forest pollen types (Phyllanthaceae, Apocynaceae (Alstonia), Moraceae and Arecaceae) supports the notion that moisture availability also influences plant presence. For the broader Ruisasi 2 landscape, Cyperaceae are not interpreted as strict swamp taxa, but occupants of moist ground, particularly at wooded habitat margins (Stephens and Dowling 2002).

Higher occurrences of ferns and herbaceous taxa in Ruisasi 2 at >5,800-4,500 cal BP are replaced by increasing Pandanus, particularly after c. 3,000 cal BP. Reflected in both Pteridophyta and Pandanus, disturbance has influenced the mixed savanna structure and composition on the Ruisasi 2 alluvial plain from before 5,800 cal BP. Two forms of vegetation disturbance are suggested in Fig. 3, shifting before and after approximately 3,000-2,500 cal BP and coinciding with the change in sediment types. This corresponds well in timing with the beginning of permanent human settlements across the Caution Bay catchment. 
Charcoal occurs in low concentrations in the majority of earlier samples, as in Zone 1a. Fire was initially present in the environment, but exerted little influence on Ruisasi 2's vegetation communities until burning gradually increased, beginning c. 3,000-2,500 cal BP. Zone 1a spans the mid Holocene in date, where climate signals in the results are strongest. The mid Holocene period was a time of climatic optimum with higher effective precipitation than at present, with enhanced humidity, greater than present wet season temperatures and higher dry season precipitation, reducing annual climate seasonality (Hiscock and Kershaw 1992; Denniston et al. 2013; Reeves et al. 2013; Field et al. 2017). The mid Holocene (7,500-4,500 yr BP) was a period of regionally enhanced Indonesian-Australian Summer Monsoon (IASM) conditions driven by rising sea levels and flooding of the Sahul and Sunda continental shelves, along with factors such as a northward shift in mean Intertropical Convergence Zone position (Griffiths et al. 2009; Denniston et al. 2013). A period of increased precipitation together with low evaporation would not only have reduced the potential for mid Holocene landscape burning at Ruisasi 2, but would also have invoked changes in ground surface behaviour and distribution of rainfall, with local hydrology being affected by drainage, soil and climate. Under consistently greater (high-energy) monsoonal rainfall, the ground surfaces on the lowland alluvial plains would have been altered by erosion during wet season floods, for instance with gravel, sand and smaller particles differentially trapped; the small cultural materials and/or shell would also have been transported into and trapped on the site. This wetness would have changed drainage conditions and the structure and flow of watercourses along the way. Herb layers of grasses, sedges, creepers and in the case of Ruisasi 2 also ferns, would have been the first responders to such ground surface changes prior to c. 3,0002,500 cal BP. Waterlogging as in SU2 would also have disfavoured woody plants at that time.

Ferns constitute a significant proportion of many tropical plant communities (Walker 1994; Kirkman et al. 2004). Walker (1994) documents how wet-landslip exposure of tropical soils results in lower nutrient status, conditions where ferns are highly competitive, and provides examples of exposed, disturbed tropical soils being colonized by thicket forming vine-like ferns. These spread laterally by extensive rhizomes that grow at or just below the ground surface, from which fronds emerge at irregular intervals and form thickets. In turn, fern thickets facilitate establishment and growth of associated plants by increasing soil stability, soil organic matter and/or soil nutrients, highlighting the important role of ferns in tropical succession (Walker 1994; Kirkman et al. 2004). At Ruisasi 2 fern growth would have been particularly encouraged by high moisture and low ground disturbance from fire during the mid Holocene. As the Ruisasi 2 pollen sequence also shows, an ongoing colonisation of altered ground surfaces by pioneer plants was eventually accompanied by successional development in which new woody taxa replaced and/or intermixed with earlier invaders, creating a mixed savanna mosaic. Alongside shifting Pandanus, the transitional understorey of broadleaf trees and shrubs at $>5,800-4,500 \mathrm{cal} \mathrm{BP}$ (and then through to c. 3,000 cal BP) represents this later successional stage under a warmer and wetter climate.

In areas that are seasonally dry such as Caution Bay, the modern post-wet season plant succession is commonly retarded by fire. In sedge grasslands frequent fires damage and kill pioneering ferns, grasses and herbs, and in exceptionally dry periods will encroach upon established woody vegetation and open its structure. Fire will also alter floristic compositions (Paijmans 1976). A fire-maintained ecosystem is apparent after c. 3,000-2,500 cal BP, coincident in timing with the start of permanent human settlements in Caution Bay, especially along the coast. Settlement in the broader region is associated with landscape burning (for hunting) and gardens (for agriculture). Archaeological discussions from Edubu 1 (Fig. 1) interpret disturbances at this site as including firing of the local vegetation to maintain savanna habitats for macropods, particularly for hunting Macropus agilis (agile wallaby) (McNiven et al. 2012). Eden (1974) argues that the potential for environmental impact from shifting cultivation is considerable, given that the life of individual fields would have been only three to four years. Eden (1974) concludes that the distribution of 
the Port Moresby savanna cannot be accounted for only by environmental factors, but is also a product of burning by humans. The transition phase between localised water disturbance (climate) effects and landscape fire through human activities occurs through the mid and into the later Holocene in SU2 into SU1, burning increasing further at approximately 1,250 and $290 \mathrm{cal} \mathrm{BP}$, for example. More Pandanus at Ruisasi 2 coincides with an increased level of burning and the diverse and ferny undergrowth was largely removed. Therefore, from c. 3,000-2,500 cal BP (onwards), human activity in the catchment, including use of fire, appears to have encouraged Pandanus growth but impacted local ground cover composition resulting in less grass, a decline in forb diversity with the development of weedy types such as Asteraceae, and markedly fewer ferns, in turn reducing their role in soil stability, influencing SU2. Fire has also affected the density of lower-growing trees, in which palms usually abound (Paijmans 1976). Various species of Rubiaceae are common in the woody undergrowth of New Guinea forests. Taxa such as Flagellaria are also often climbers within thicket and/or forest undergrowth (Paijmans 1976; Conn and Damas 2006). These three examples (palms, Rubiaceae and Flagellaria) all progressively decline at Ruisasi 2. For this region, Rowe et al. (2013) similarly record increases in Pandanus, a decline in broadleaf trees and shrubs, and a rise in charcoal concentrations in the past 2,000 years. In combination, such works confirm wider changes in the catchment, parallel with similar changes noted outside the Caution Bay area (for example, Osborne et al. 1993; McNiven et al. 2010).

Ruisasi 2 Zone 2 is dated to the past $<500$ years. The regional Australian-Indonesian climatic transition from the mid to the late Holocene is marked by a sustained decline in rainfall (and progressively weakened and unstable IASM from 4,200-1,500/1,200 yr BP, Denniston et al. 2013). Diminished and/or variable rainfall is recorded in tropical Australia for the late Holocene (Denniston et al. 2013), the Indo-Pacific Warm Pool (Gagan et al. 2004) and at sites across the Pacific (Koutavas and Joanides 2012). This is connected to an increase in the frequency and/or amplitude of ENSO since c. 5,000-3,000 yr BP (Denniston et al. 2013). In northern Australia, Shulmeister and Lees (1995) and Field et al. (2017) have documented pollen evidence for more frequent late Holocene drought. Wannum, a lake in central-eastern PNG, also exhibits increases in dry land grasses, secondary forest and burning during the late Holocene (Prebble et al. 2010). Wetlands in the Port Moresby foothills record a decrease in water depth together with tree loss c. 1,000-700 yr BP (Osborne et al. 1993), and Haberle and Ledru (2001) link increases in charcoal abundances in late Holocene sequences from highland PNG and Indonesia to increased frequencies of burning, considered to have partly originated from ENSO drought. Likewise, climate variability appears to have increased the potential for fire at Ruisasi 2. It would have notably increased the vulnerability of plant biomass to the impact of burning from expanded Lapita/post-Lapita culture populations toward the present day; there was new village occupation after 2,000 cal BP, but with greater mobility/interaction, cultural specialisation and item exchange $<800$ cal BP (David et al. 2016a). Collectively, climate and people have created an open ecosystem dominated by woody firetolerant opportunist plants. Climate variability does not appear to have dramatically affected sediment moisture availability at the Ruisasi 2 site. To a degree, the site's sediments may have buffered reduced rainfall changes between mid and late Holocene conditions, with the clay dominated soil maintaining a water holding capacity, so that at least seasonally, water drainage remained impaired and periodic saturation occurred. Such indications of water retention amidst variable climates suggest that there was a localised freshwater resource available in Caution Bay, highlighting a landscape capable of supporting the increased amounts of settlement seen in the archaeological records.

In Ruisasi 2 Zone 2b, the increase in Pandanus during Zone 2a is discontinued and the decline in Poaceae stabilises (beginning c. 290 cal BP). Ferns are also nearly absent and Cyperaceae are reduced. This modern period incorporates the lowest plant diversity and highest record of burning in the sequence. The pollen record of the previous c. 300 years shows the landscape effects of the final phase of prehistory transitioning 
into the time of European contact and the colonial period. The sediments are likely to be disturbed and potentially mixed leading into the modern day.

As Kruger (2015, p 117) observes, since the identity of contemporary savannas is contingent on past events, their ecology can properly be understood only with the knowledge of their past. The palaeoecological and archaeological results from Ruisasi 2 record some 5,800 years of landscape change. Caution Bay includes numerous Holocene plant-to-plant interactions, climate-vegetation formations and human-landscape relationships. This paper enhances our capacity to understand long-term changes in lowland PNG environments, and demonstrates that savanna vegetation is inherently dynamic and that its tree and grass components interact by many mechanisms.

\section{Acknowledgements}

This research was conducted under the Australian Research Council (ARC) Centre of Excellence for Australian Biodiversity and Heritage (CE170100015). Warm thanks to the people of Porebada, Boera, Papa and Lealea for their field assistance and local insights into the Caution Bay environment. Thanks to Laura Bates, Sean Connaughton, Jeanie Maingu, Lesley Muke, Matilda Kopunye and Stanley Kuri for assistance with fieldwork and to Alan Hogg (Waikato Radiocarbon Dating Laboratory) for assistance with radiocarbon determinations. The assistance received from the PNG National Museum and Art Gallery is gratefully acknowledged. Within the College of Arts, Society and Education (James Cook University), thanks to Helene Peck and Cailey Maclaurin for their laboratory processing of shell materials and to Michael Bird for draft comments. Within Monash University, thanks to Ursula Pietrzak for laboratory advice and Kara Rasmanis for drafting the figures. We further thank Laureate FL140100044 (What is Natural? Humans megafauna and climate in northern Australia) for support during the writing up of the results. SU is the recipient of an Australian Research Council Future Fellowship (project number FT120100656). Both James Cook University and Monash University provided institutional support throughout this research.

\section{References}

Anshari G, Kershaw AP, van der Kaars S (2001) A late Pleistocene and Holocene pollen and charcoal record from peat swamp forest, Lake Sentarum Wildlife Reserve, West Kalimantan, Indonesia. Palaeogeogr Palaeoclimatol Palaeoecol 171:213-228

Aplin K, Rowe C, Peck H, Asmussen B, Ulm S, Faulker P, Richards T (2016) The natural setting of Caution Bay: Climate, landform, biota and environmental zones. In: Richards T, David B, Aplin K, McNiven IJ (eds) Archaeological research at Caution Bay, Papua New Guinea. Oxbow, Oxford, pp 75-111

APSA Members (2007) The Australasian Pollen and Spore Atlas V1.0. Australian National University, Canberra. http://apsa.anu.edu.au/. Accessed June-August 2013

Bird MI, Taylor D, Hunt C (2005) Palaeoenvironments of insular Southeast Asia during the Last Glacial Period: A savanna corridor in Sundaland? Quat Sci Rev 24:2,228-2,242

Bird MI, O'Grady D, Ulm S (2016) Humans, water, and the colonization of Australia. Proc Natl Acad Sci USA 113:11,477-11,482 
Bird MI, Beaman RJ, Condie SA, Cooper A, Ulm S, Veth P (2018) Palaeogeography and voyage modeling indicates early human colonization of Australia was likely from Timor-Roti. Quat Sci Rev 191:431-439. doi.org/10.1016/j.quascirev.2018.04.027

Blake DH, Saunders JC, McAlpine JR, Paijmans K (2010) Land-form types and vegetation of eastern Papua. (CSIRO Land Research Surveys 32) CSIRO, Melbourne

Bourlière F, Hadley M (1983) Present day savannas: an overview. In: Bourlière F (ed) Tropical savannas (Ecosystems of the world 13). Elsevier, Amsterdam, pp 1-18

Bowman DMJS, Wilson BA, McDonough L (1991) Monsoon forests in northwestern Australia 1: Vegetation classification and the environmental control of tree species. J Biogeogr 18:679-686

Bronk Ramsey B (2009) Bayesian analysis of radiocarbon dates. Radiocarbon 51:337-360

Brown CA (2008) Palynological techniques, 2nd edn. American Association of Stratigraphic Palynologists, Dallas, Texas

Bureau of Meteorology (BoM) (2017) Weather and climate data. Commonwealth of Australia http://www.bom.gov.au/climate/data/. Accessed November 2017

Clunie NMU (1995) The vegetation. In: Womersley JS (ed) Handbook of the flora of Papua New Guinea, vol 1. Melbourne University Press, Melbourne. pp 1-12

Conn BJ, Damas KQ (2006) Guide to trees of Papua New Guinea. http://www.pngplants.org/PNGtrees. Accessed November 2013

David B, Duncan B, Ash J, Skelly R, Araho N (2009) Cultural heritage at the LNG Facility site at Portion 2456, Papua New Guinea: review of the ethnography, archaeology and new findings. (Cultural Heritage Report Series 39) Monash University, Clayton

David B, Richards T, Skelly R, McNiven IJ, Levavesley M (2016a) Archaeology in Port Moresby and the southern lowlands of Papua New Guinea: intellectual and historical contexts for Caution Bay. In: Richards T, David B, Aplin K, McNiven IJ (eds) Archaeological research at Caution Bay, Papua New Guinea: cultural, linguistic and environmental setting. Oxbow, Oxford, pp 9-25

David B, Richards T, Skelly R, Walker S, Leavesley M, Ash J, Mandui H (2016b) Archaeological surveys at Caution Bay. In: Richards T, David B, Aplin K, McNiven IJ (eds) Archaeological research at Caution Bay, Papua New Guinea: cultural, linguistic and environmental setting. Oxbow, Oxford, pp 113-143

Davies H, Smith I (1971) Geology of eastern Papua. Geol Soc Am Bull 82:3,299-3,312

Davis OK (1994) Aspects of archaeological palynology: methodology and appliations. (AASP Contributions Series 29). American Association of Stratigraphic Palynologists Foundation, Dallas

Denniston RF, Wyrwoll K-H, Polyak VJ, et al (2013) A stalagmite record of Holocene IndonesianAustralian summer monsoon variability from the Australian tropics. Quat Sci Rev 78:155-168

digim'Rina LS, Richards T, David B, et al (2016) Koita and Motu landscapes and seascapes of Caution Bay. In: Richards T, David B, Aplin K, McNiven IJ (eds) Archaeological research at Caution Bay, Papua New Guinea: cultural, linguistic and environmental setting. Oxbow, Oxford pp 53-63

Duckett MK (2016) Papua New Guinea. National Geographic Society. http://www.nationalgeographic.com/travel/features/best-trips-2017/\#top. Accessed December 2016 
Eden MJ (1974) The origin and status of savanna and grassland in southern Papua. Trans Inst Br Geogr 63:97-110

Eden MJ (1993) Swidden cultivation in forest and savanna in lowland southwest Papua New Guinea. Hum Ecol 21:145-166

Fairhead J, Leach M (1996) Misreading the African landscape: society and ecology in a forest-savanna mosaic. Cambridge University Press, Cambridge

Field E, McGowan HA, Moss PT, Marx SK (2017) A late Quaternary record of monsoon variability in the northwest Kimberley. Quat Int 449:119-135

Gagan MK, Hendy EJ, Haberle SG, Hantoro WS (2004) Post-glacial evolution of the Indo-Pacific Warm Pool and El Nino-Southern oscillation. Quat Int 118-119:127-143

Garrett-Jones S (1979) Evidence for changes in Holocene vegetation and lake sedimentation in the Markham Valley, Papua New Guinea. Dissertation, Australian National University, Canberra

Gillison AN (1983) Tropical savannas of Australia and the southwest Pacific. In: Bourlière F (ed) Tropical savannas (Ecosystems of the world 13). Elsevier, Amsterdam, pp 183-238

Gressit JL (2012) Biogeography and ecology of New Guinea. Springer, Dordrecht

Griffiths ML, Drysdale RN, Gagan MK, et al (2009) Increasing Australian-Indonesian monsoon rainfall linked to early Holocene sea-level rise. Nat Geosci 2:636-639

Grimm EC (1987) CONISS: a FORTRAN 77 program for stratigraphically constrained cluster analysis by the method of incremental sum of squares. Comput Geosci 13:13-35

Grimm EC (1991) Tilia Program Ver. 2.0 B4. Illinois Museum, Springfield

Haberle SG (1995) Identification of cultivated Pandanus and Colocasia in pollen records and the implications for the study of early agriculture in New Guinea. Veget Hist Archaeobot 4:195-210

Haberle SG (1998) Late Quaternary vegetation change in the Tari Basin, Papua New Guinea. Palaeogeogr Palaeoclimatol Palaeoecol 137:1-24

Haberle SG (2013) Quaternary palynology in New Guinea. Tropical Archaeobotany: Applications and New Developments 22:172-220

Haberle SG, Ledru MP (2001) Correlation among charcoal records of fires from the past 16,000 years in Indonesia, Papua New Guinea and Central and South America. Quat Res 55:97-104

Haberle SG, Lentfer C, O’Donnell S, Denham T (2012) The palaeoenvironments of Kuk Swamp from the beginnings of agriculture in the highlands of Papua New Guinea. Quat Int 249:29-139

Hall SA (1990) Progressive deterioration of pollen grains in south-central U.S. rockshelters. J Palynol Palaeobot 91:159-169

Hiscock P, Kershaw AP (1992) Palaeoenvironments and prehistory of Australia's tropical Top End. In: Dodson J (ed) The naïve lands: prehistory and environmental change in Australia and the southwest Pacific. Longman, Melbourne, pp 43-75

Hope GS (2007) Paleoecology and palaeoenvironments of Papua. In: Marshall AJ, Beehler BM (eds) The ecology of Papua, part 1. Periplus Editions, Singapore, pp 255-266 
Hope GS (2009) Environmental change and fire in the Owen Stanley ranges, Papua New Guinea. Quat Sci Rev 28:2,261-2,276

Hope GS, Aplin K (2005) Environmental change in the Aru Islands. Terra Australis 22:25-40

Jones DL, Clemesha SC (1978) Australian ferns and fern allies. Reed Publications, Sydney

Jones R (1980) Hunters in the Australian coastal savanna. In: Harris DR (ed) Human ecology in savanna environments. Academic Press, New York, pp 107-146

Jones R, Bowler J (1980) Struggle for the savanna: northern Australia in ecological and prehistoric perspective. In: Jones R (ed) Northern Australia: options and implications. (Research School of Pacific Studies, School Seminar Series 1) Australian National University, Canberra, pp 3-31

Kirkman LK, Coffey KL, Mitchell RJ, Moser EB (2004) Ground cover recovery patterns and life-history traits: implications for restoration obstacles and opportunities in a species-rich savanna. J Ecol 92:409-421

Koutavas A, Joanides S (2012) El Nino-Southern Oscillation extremes in the late-Holocene and Last Glacial Maximum. Palaeoceanogr 27:42-48

Kruger F (2015) Palaeobiology of the South African savanna and lessons for modern ecologists. Trans R Soc South Africa 70:117-125

Lonely Planet (2017) Papua New Guinea and beyond. https://www.lonelyplanet.com/papua-new-guinea. Accessed December 2017

Mabbutt JA, Heyligers PC, Scott RM, Pullen R, Fitzpartrick EA, McAlpine JR, Speight JG (1965) Lands of the Port Moresby-Kairuku area, territory of Papua New Guinea. (CSIRO Land Research Series 14)

Commonwealth Scientific and Industrial Research Organization, Melbourne

McDonald RC, Isbell RF, Speight JG, Walker J, Hopkins MS (1998) Australian soil and land survey: field handbook. CSIRO Publishing, Melbourne

McNiven IJ, Bruno D, Ken A, et al (2010) Historicising the present: Late Holocene emergence of a rainforest hunting camp, Gulf Province, Papua New Guinea. Aust Archaeol 71:41-56

McNiven IJ, David B, Richards T, et al (2011) New direction in human colonisation of the Pacific: Lapita settlement of south coast New Guinea. Aust Archaeol 72:1-6

McNiven IJ, David B, Aplin K, Asmussen B, Mialanes J, Rowe C, Richards T (2012) Terrestrial engagements by terminal Lapita maritime specialists on the southern Papuan coast. Terra Australis 34:121156

Nix HA, Kalma JD (1972) Climate as a dominant control in the biogeography of northern Australia and New Guinea. In: Walker D (ed) Bridge and barrier: the natural and cultural history of Torres Strait. Research School of Pacific Studies, Department of Biogeography and Geomorphology, Australian National University, Canberra, pp 61-91

Olsen DM, Loucks CJ, Dinerstein E (2001) Terrestrial ecoregions of the world: a new map of life on earth. BioScience 51:933-938

Osborne PL, Humphreys GS, Polunin NVC (1993) Sediment deposition and late Holocene environmental change in a tropical lowland basin: Waigani Lake, Papua New Guinea. J Biogeogr 20:599-613 
Paijmans K (1975) Explanatory notes to the vegetation map of Papua New Guinea (CSIRO Land Research Series 35). CSIRO Publishing, Melbourne

Paijmans K (1976) New Guinea vegetation. CSIRO Publishing, Australian National University Press, Melbourne and Elsevier, Amsterdam

Peel MC, Finlayson BL, McMahon TA (2007) Updated world map of the Köppen-Geiger climate classification. Hydrol Earth Syst Sci Discuss 4:439-473

Petchey F, Ulm S, David B, et al (2012) 14C marine reservoir variability in herbivores and deposit-feeding gastropods from an open coastline, Papua New Guinea. Radiocarbon 54:967-978

Petchey F, Ulm S, David B, et al (2013) High-resolution radiocarbon dating of marine materials in archaeological contexts: Radiocarbon marine reservoir variability between Anadara, Gafrarium, Batissa, Polymesoda spp. and Echinoidea at Caution Bay, southern coastal Papua New Guinea. Archaeol Anthropol Sci 5:69-80

Phear S (2008) Subsistence and island landscape transformations: Investigating monumental earthworks in Ngaraard State, Republic of Palau. Micronesia. Islands of inquiry: Colonisation, seafaring and the archaeology of maritime landscapes. Terra Australis 29:301-324

Prebble M, Sim R, Finn J, Fink D (2005) A Holocene pollen and diatom record from Vanderlin Island, Gulf of Carpentaria, lowland tropical Australia. Quat Res 64:357-371

Prebble M, Kennedy J, Southern W (2010) Holocene lowland vegetation change and human ecology in Manus Province, Papua New Guinea. Terra Australis 32:299-321

Reeves JM, Bostock HC, Ayliffe LK, et al (2013) Palaeoenvironmental change in tropical Australasia over the last 30,000 years-a synthesis by the OZ-INTIMATE group. Quat Sci Rev 74:97-114

Reimer P, Bard E, Bayliss A, et al (2013) IntCal13 and Marine13 radiocarbon age calibration curves 050,000 years cal BP. Radiocarbon 55:1,869-1,887

Ridpath MG (1985) Ecology in the wet-dry tropics: how different. In: Ridpath MG, Corbett LK (eds) Ecology of the wet-dry tropics. Proceedings of a joint symposium with the Australian Mammal Society, Darwin, May, 1983. (Proceedings of the Ecological Society of Australia 13) Ecological Society of Australia, Darwin, pp 3-20

Rowe C (2012) Modern surface pollen from the Torres Strait Islands: Exploring north Australian vegetation heterogeneity. Terra Australis 34:413-434

Rowe C, McNiven IJ, David B, Richards T, Leavesley M (2013) Holocene pollen records from Caution Bay, southern mainland Papua New Guinea. Holocene 23:1,130-1,142

Samanta S, Pal DK (2016) Change detection of land use and land cover over a period of 20 years in Papua New Guinea. Nat Sci 8:138-151

Shearman P, Bryan J (2011) A bioregional analysis of the distribution of rainforest cover, deforestation and degradation in Papua New Guinea. Aust Ecol 36:9-24

Shearman PL, Bryan JE, Ash J, Hunnam P, Mackey B, Lokes B (2008) The state of the forests of Papua New Guinea: mapping the extent and condition of forest and measuring the drivers of forest change in the period 1972-2002. University of Papua New Guinea, Port Moresby, Papua New Guinea 
Shulmeister J (1992) A Holocene pollen record from lowland tropical Australia. Holocene 2:107-116

Shulmeister J, Lees BG (1995) Pollen evidence from tropical Australia of an ENSO dominated climate at c. 4000 BP. Geomorphology 5:521-534

Skelly R, David B (2017) Hiri: Archaeology of long-distance maritime trade along the south coast of Papua New Guinea. University of Hawai'i Press, Honolulu

Skelly R, David B, Petchey F, Leavesley M (2014) Tracking ancient beach-lines inland: 2600-year-old dentate-stamped ceramics at Hopo, Vailala River region, Papua New Guinea. Antiquity 88:470-487

Slik JF, Aiba SI, Bastian M, Brearley FQ, Cannon CH, Eichhorn KA, Marjokorpi A (2011). Soils on exposed Sunda Shelf shaped biogeographic patterns in the equatorial forests of Southeast Asia. Proc Natl Acad Sci USA 108:12,343-12,347

Smol JP, Birks HJB, Last WM (2001) Tracking environmental change using lake sediments, vol 3, Terrestrial, algal, and siliceous Indicators. Springer, Berlin

Stephens KM, Dowling RM (2002) Wetland plants of Queensland. CSIRO Publishing, Melbourne

Sturman A, Tapper N (2005) The weather and climate of Australia and New Zealand. Oxford University Press, Melbourne

Takeuchi WN (2007) Introduction to the flora of Papua. In: Marshall AJ, Beehler BM (eds) The ecology of Papua (The Ecology of Indonesia 6). Periplus Editions, Singapore, pp 269-302

Van der Kaars S (1991) Palynology of eastern Indonesian marine piston-cores: a Late Quaternary vegetational and climatic record for Australasia. Palaeogeogr Palaeoclimatol Palaeoecol 85:239-302

Waikato Radiocarbon Dating Laboratory (2017) AMS processing. Unpublished technical report, University of Waikato. http://www.radiocarbondating.com/_data/assets/pdf_file/0010/387712/Waikato-RadiocarbonDating-Laboratory-AMS-Processing-Technical-Report-2017.pdf

Walker LR (1994) Effects of fern thickets on woodland development on landslides in Puerto Rico. J Veget Sci 5:525-532.

Whitlock C, Higuera PE, McWethy DB, Briles C (2010) Palaeoecological perspectives on fire ecology: revisiting the fire-regime concept. Open Ecol J 3:6-23Ward, I., Larcombe, P., Carson, A., Lane, A. 2016. Archaeological assessment of coastal and marine development sites: case study from James Price Point, WA. J. Roy. Soc. WA, 99(2), 31-46. 